JOURNAL OF

HORTICULTURAL

SCIENCES
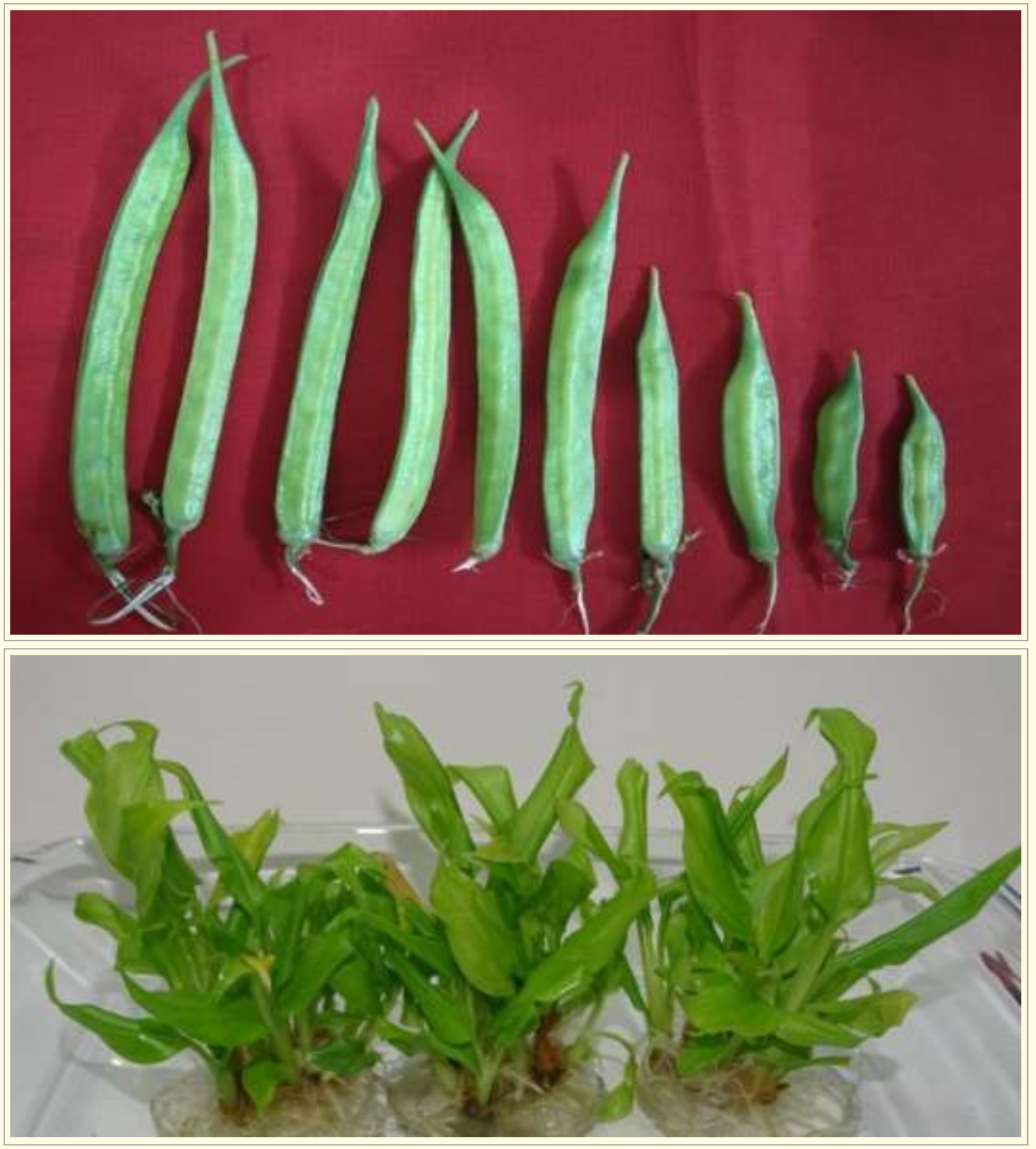

Society for Promotion of Horticulture

ICAR - Indian Institute of Horticultural Research, Bengaluru - 560089 


\section{JOURNAL OF HORTICULTURAL SCIENCES}

Volume 16

Issue 1

June 2021

\section{ONTENTS}

\section{In this Issue}

\section{Review}

Moringa (Moringa oleifera L.): An underutilized and traditionally valued

tree holding remarkable potential

Jattan M., Kumari N., Raj Kumar, Kumar A., Rani B., Phogat D.S.,

Kumar, S. and Kumar, P.

\section{Original Research in Papers}

Characterization and evaluation of mountain sweet thorn

(Flacourtia montana J. Grah) collections

Tripathi P.C., Ganeshan S., Radhika V. and Shetti D.L.

Optimization of methodology for the extraction of polyphenolic compounds

with antioxidant potential and á-glucosidase inhibitory activity from jamun

(Syzygium cumini L.) seeds

Arivalagan M., Priyanka D.R. and Rekha A.

Genetic variability studies in amaranthus (Amaranthus spp.)

Agadi A.H., Kolakar S., Lakshmana D., Nadukeri S. and Hanumanthappa M.

Morpho-physiological parameters associated with chlorosis resistance to

iron deficiency and their effect on yield and related attributes in potato

(Solanum tuberosum L.)

Challam C., Dutt S., Sharma J., Raveendran M. and Sudhakar D.

Responses of different Okra (Abelmoschus esculentus) cultivars to water

deficit conditions

Ayub Q., Khan S.M., Hussain I., Naveed K., Ali S., Mehmood A., Khan M.J.,

Haq N.U., Shehzad Q.

Induced variability for yield and its attributing traits in cluster bean

[Cyamopsis tetragonoloba (L. ) Taub] through gamma irradiation

Lavanya H.N., Mishra S., Sood M., Aghora T.S., Anjanappa M., Rao V.K. and Reddy A.B.

In vitro multiplication protocol for Curcuma mangga : Studies on carbon,

Waman A.A., Bohra P., Karthika Devi R. and Pixy J. 
Effect of fungicide and essential oils amended wax coating on quality and shelf life of sweet orange (Citrus sinensis Osbeck)

Bhandari M., Bhandari N. and Dhital M.

Post-harvest quality and quantification of betalains, phenolic compounds and antioxidant activity in fruits of three cultivars of prickly pear

(Opuntia ficus-indica L. Mill)

Gonzalez F.P.H., Saucedo V.C., Guerra R.D., Suarez E.J., Soto H.R.M. Lopez J.A.,

Garcia C.E. and Hernandez R.G.

Soil microbial community dynamics as influenced by integrated nutrient management practices in sweet basil (Ocimum basilicum L.) cultivation Baraa AL-Mansour and D. Kalaivanan

Effect of spectral manipulation and seasonal variations on cut foliage production and quality of Philodendron (Philodendron 'Xanadu')

Sujatha A. Nair, Laxman R.H. and Sangama

\section{Short Communications}

Studies on mutagenic sensitivity of seeds of pummelo (Citrus maxima Merr.)

Sankaran M., Kalaivanan D. and Sunil Gowda D.C.

Isolation and characterization of microsatellite markers from

Garcinia indica and cross species amplification

Ravishankar K.V., Vasudeva R., Hemanth B., Nischita P., Sthapit B.R.,

Parthasarathy V.A. and Rao V.R. 


\title{
Effect of fungicide and essential oils amended wax coating on quality and shelf life of sweet orange (Citrus sinensis Osbeck)
}

\author{
Bhandari M. ${ }^{1}$, Bhandari N. ${ }^{* 1}$ and Dhital M. ${ }^{2}$ \\ ${ }^{1}$ Institute of Agriculture and Animal Science, Rampur, Chitwan, Nepal \\ ${ }^{1 *}$ Institute of Agriculture and Animal Science, Gauradaha, Jhapa, Nepal \\ ${ }^{2}$ Agriculture and Forestry University, Rampur, Chitwan, Nepal \\ ${ }^{*}$ Corresponding author e-mail: iaasnirajan@gmail.com
}

\begin{abstract}
Laboratory research was conducted to study the effect of wax amended coating on the shelf life of Citrus sinensis Osbeck during 2017-18 at Rampur, Chitwan. The experiment was conducted in single factor Completely Randomized Design (CRD) with nine treatments and four replications. The treatments consisted of carbendazim and three essential oils viz. lemongrass, mentha and eucalyptus oil at two different concentrations of $0.1 \%$ and $0.5 \%$, all of them infused with $10 \%$ wax emulsion. The wax treatment devoid of fungicide and essential oils served as control. The application of essential oils with wax improved shelf life and enhanced juice retention, firmness, titratable acidity, vitamin $C$ and disease reduction. But total soluble solid was found higher in fruits treated with wax emulsion only. The highest shelf life and disease control was obtained with wax with $0.5 \%$ carbendazim but waxing with $0.5 \%$ eucalyptus oil and $0.5 \%$ lemongrass oil can be better alternatives considering their superior performance in environmental aspects, consumer preferences and quality parameters like juice retention, firmness, titratable acidity and vitamin $C$.
\end{abstract}

Keywords : Carbendazim, Eucalyptus oil, Green mold, Lemongrass oil, Post-harvest

\section{INTRODUCTION}

Sweet Orange (Citrus sinensis Obseck) is an economically important citrus fruit of the mid hill region of Nepal. The mid hill region of Nepal (1000 to 1500 masl altitude) has a comparative advantage in the production of sweet orange over traditional crops (rice, wheat, maize etc). Sweet orange is the second most grown citrus crop in Nepal after Mandarin in terms of area and production (MOALD, 2020). The oranges in the Nepalese agricultural market have to compete with products coming from neighboring countries like India and China. The cost of production of sweet orange is higher due to high input costs, the need for hybrid budded and grafted saplings and intensive labor requirements to grow the crop which has forced the grower to think about improving postharvest management practices. The lack of suitable storage and preservation techniques forces the farmers to sell sweet oranges before their horticultural maturity and just after picking. The unaffordable postharvest preservation has led to a negative effect on the citrus enterprises in Nepal (Kaini, 2013).

Green mold (Penicillium digitatum Sacc.) and blue mold (Penicillium italicum Wehmer) are the most economically important postharvest pathogens of sweet orange causing significant losses (Abd-El-Khair and Hafez, 2006; El-Otmani et al., 2011; Papoutsis et al., 2019). Currently, the control of green and blue mold is accomplished by pre-and postharvest application of chemical fungicides such as carbendazim, imazalil, thiabendazole, pyrimethanil, fludioxonil, prochloraz and and guazatine (Danderson, 1986; Ismail and Zhang, 2004; Smilanick et al., 2006; Smilanick et al., 2008; Berk, 2016; Joshi et al., 2020). Broadly, such fungicides inhibit the ergosterol synthesis, mitochondrial electron transport and synthesis of multi-site enzymes, protein and nucleic acid thereby kill or inhibit fungi or fungal spore 
germination (Yang et al., 2011). However, synthetic fungicides are used as the conventional ways of reducing postharvest rots which have many drawbacks including high cost, handling hazards, concern about pesticide residue on fruit and a threat to human health and environment (Tzortzakis, 2009). Various synthetic fungicides were identified as toxic and carcinogenic by various researchers (Rouabhi, 2010; Singh et al., 2016). Pathogens also developed resistance against extensive use of synthetic fungicides resulting in declining fungicidal efficiency (Fogliata et al., 2000; Hao et al., 2011).

The application of essential oil amended coatings has been developed as a novel and eco-friendly approach to control postharvest microbes, maintain fruit quality and improve shelf life (Alam et al.,2017; Jhalegar et al., 2015). The essential oils do not have only antifungal properties, but the secondary metabolites also have antioxidant and bio-regulatory properties $(\mathrm{Du}$ Plooy et al., 2009; Jhalegaret al., 2014; Bagamboula et al., 2004; Hendel et al., 2016). The increasing demand for organic fruits encourages replacing synthetic fungicides with safer alternatives. The volatility, ephemeral nature and biodegradability of essential oils make it comparatively advantageous for the treatment of postharvest citrus disease (Ameziane et al., 2007). The synergism between the components in volatiles may be the reason behind the fungitoxic property of essential oils. Therefore, there is a minimal possibility of resistance. The application of essential oils with wax increases its longevity and reduces the amountof essential oils required per fruit. Therefore, the study was made to compare various wax amended treatments, their efficacy and their impact on postharvest parameters.

\section{MATERIALS AND METHODS}

\section{Experimental site and fruit material}

The present investigation was carried out at Agriculture and Forestry University (AFU), Rampur, Chitwan during the year 2017-2018. The location of the site is $27^{\circ} 40^{\prime} \mathrm{N}$ and $85^{\circ} 19^{\prime} \mathrm{E}$ with an elevation of 228 meter above sea level. The experiment was conducted in a cool and humid winter season. The local variety of sweet orange handpicked from the farmers orchard of Sindhuli was transported to Chitwan for the experiment. The fruits were kept in the tagged plastic trays during the storage period at room temperature. The average weight of fruit was $144.56 \mathrm{~g}$. The average seed number was 10 . The average juice content of fruit was $84.19 \mathrm{ml}$.

\section{Experimental design}

The experiment was laid out in single factor Completely Randomized Design (CRD) with nine treatments and four replications. There were a total of 36 experimental trays having 12 fruits per tray. The treatments were finalized based on the findings of Tripathi et al., (2004), Jhalegar et al., (2015) and Rokaya et al., (2016).

\section{Treatments details}

T1: $10 \%(\mathrm{w} / \mathrm{v})$ wax emulsion with $0.1 \%(\mathrm{v} / \mathrm{v})$ Lemongrass (Cymbopogon flexuosus) oil

T2: $10 \%(\mathrm{w} / \mathrm{v})$ wax emulsion with $0.5 \%(\mathrm{v} / \mathrm{v})$ Lemongrass (Cymbopogon flexuosus) oil

T3: $10 \%(\mathrm{w} / \mathrm{v})$ wax emulsion with $0.1 \%(\mathrm{v} / \mathrm{v})$ Mentha (Mentha arvensis) oil

T4: $10 \%(\mathrm{w} / \mathrm{v})$ wax emulsion with $0.5 \%(\mathrm{v} / \mathrm{v})$ Mentha (Mentha arvensis) oil

T5: $10 \%(\mathrm{w} / \mathrm{v})$ wax emulsion with $0.1 \%(\mathrm{v} / \mathrm{v})$ Eucalyptus (Eucalyptus sp.) oil

T6: $10 \%(\mathrm{w} / \mathrm{v})$ wax emulsion with $0.5 \%(\mathrm{v} / \mathrm{v})$ Eucalyptus (Eucalyptus sp.) oil

T7: $10 \%(\mathrm{w} / \mathrm{v})$ wax emulsion with $0.1 \%(\mathrm{v} / \mathrm{v})$ Carbendazim (Bavistin)

T8: $10 \%(\mathrm{w} / \mathrm{v})$ wax emulsion with $0.5 \%(\mathrm{v} / \mathrm{v})$ Carbendazim (Bavistin)

T9: Control (dipped in 10\% wax emulsion only)

\section{Preparation of $10 \%$ wax emulsion}

Paraffin wax $\left(58-60^{\circ} \mathrm{C}\right.$, Solid LR-Grade) was used for preparing wax emulsion. Five hundred milliliter of water was boiled in a vessel and $50 \mathrm{~g}$ of wax was heated in another vessel. Fifteen milliliter of triethanolamine and ten milliliter of oleic acid was added in water as emulsifier and stabilizers. The molten wax was gradually poured into heated water with constant stirring. The stirring was rigorously done until the solution turns milky color. The milky color indicates well prepared emulsion. It was ensured that the heated wax and heated water were at same temperature while mixing. The prepared emulsion was then allowed to cool.

\section{Preparation and application of essential oils and fungicide}

The essential oils used in the experiments were prepared at Herbs Production and Processing Corporation Limited (HPPCL), Koteshwor, Kathmandu. The respective herbs collected from the Terai region of Nepal were dried, wilted and steam 
distilled to produce oils. One milliliter and five milliliter of essential oils were added in one liter of $10 \%$ wax emulsion to prepare $0.1 \%$ and $0.5 \%$ essential oils with wax emulsion. Similarly, the fungicidal solution of carbendazim was prepared by dissolving $1 \mathrm{~g}$ and $5 \mathrm{~g}$ of carbendazim (Carbendazim 50\% WP) in $1000 \mathrm{ml}$ of distilled water. One milliliten and five millititen of fungicidal solution were added in one liter of $10 \%$ wax emulsion to prepare $0.1 \%$ and $0.5 \%$ carbendazim with wax emulsion. The fruits were then dipped in the designated solutions for a few seconds, until a glossy film of wax was formed on the surface of fruits.

Table 1: Chemical constituents of essential oils used in experiment

\begin{tabular}{|l|l|}
\hline Essential oils & Chemical constituents \\
\hline Cymbopogan Flexuosus & $\begin{array}{l}\text { Geranial, Neral, Limonene, Caryophyllene, Geranyl acetate, Linalyl acetate, Citral, } \\
\text { Isogeranial, } \text {-cymene, Linalool }\end{array}$ \\
\hline Mentha arvensis & Menthol, Menthone, Isomenthone, Menthyl acetate, Limonene \\
\hline Eucalyptus sp. & Eucalyptol, Limonene, Aromadendrene, Phellamdrene, Terpinolene, Alpha terpineol \\
\hline
\end{tabular}

Source: HPPCL website

\section{Data collection and analysis}

The data about the Juice content, fruit firmness, Total Soluble Solids (TSS), Titratable Acidity (TA), vitamin $\mathrm{C}$ (ascorbic acid) and disease severity scoring was taken at every $5^{\text {th }}$ day interval. The physical (fruit firmness) and chemical (juice recovery percentage, TSS, TA and vitamin C) properties of fruits were measured by destructive sampling technique. The fruit firmness was measured bypenetrometer (effigy oil model having $8 \mathrm{~mm}$ tip) and TSS was measured by hand refractometer. Acidity and vitamin $\mathrm{C}$ was determined as per the procedure outlined by AOAC (2005). The juice recovery percentage and content was calculated by following formulae;

Juice recovery $(\%)=\frac{\text { Volume of the juice obtained }}{\text { weight of the fruit }} \times 100$

The shelf life was evaluated based on the appearance and spoilage of fruits. Fruits were considered to have reached the end of shelf life when fruits showed visible signs of decay irrespective of diameter of symptom (Obagwu and Korsten, 2003).

\section{Disease scoring and identification}

Disease scoring was done on 0-5 scale. The assessment was based on the rotted area with respect to total surface area of the sweet orange and expressed in percentage $[0=$ no infection (fruits are healthy), $1=$ infection starts $(0-5 \%$ rotting), $2=6$ $10 \%$ rotting, $3=11-15 \%$ rotting, $4=16-20 \%$ rotting, $5=>20 \%$ rotting] (Obagwu and Korsten, 2003;
Abd-El-Khair and Hafez, 2006). The rotted fruits from each replication were removed and counted. Disease severity index of decay fruits by pathogen was calculated by following formulae;

Disease severity index $(\%)=$

$\frac{\Sigma(\mathrm{nxr} 1) \ldots \ldots(\mathrm{nxr5})}{\mathrm{MN}} \times 100$ (Abd-El-Khair and Hafez, 2006)

Where, $n=$ number of decayed fruits per category, $r_{1} \cdot r_{5}=$ severity score $\mathrm{M}=$ maximum rating scale number (5), $\mathrm{N}=$ total examined fruits

The infected fruits after treatment with fungicide and essential oils were transferred to the pathology lab of AFU for the isolation of fungi. Isolation was carried out on Martin's medium (Bridson,1995). Small pieces (1-1.2 cm thickness) of rotted fruits were sterilized by dipping into $2 \%$ sodium hypochlorite solution for 5 minutes and then washed several times with distilled water and finally dried on sterile filter paper (AbdEl-Khair and El-Mougy, 2003). The fully sterilized pieces were then transferred onto the surface of the medium in sterilized Petri-plates. Inoculated plates were incubated at $25^{\circ} \mathrm{C}$ for 3-5 days. Hyphal tip technique was followed for purification of the isolated fungi. Barnett and Hunter technique was used to identify fungal cultures (Barnett and Hunter, 1987).

The temperature and relative humidity of the experimental room was recorded daily. The average minimum temperature was recorded $12.88^{\circ} \mathrm{C}$ while the average maximum temperature was recorded $16.16^{\circ} \mathrm{C}$. The average minimum humidity was $86.04 \%$ while the average maximum 
humidity was $91.73 \%$. The climate was mostly cloudy during the experiment with a few instances of drizzles. The data were entered into Microsoft Excel 2016 and analysis was carried out by using R- Studio version 4.0.2. Both descriptive and inferential analysis was carried out. Interpretations were made based on results, which were assisted by qualitative and quantitative data/information.

\section{RESULTS}

\section{Juice recovery percentage}

Juice recovery percentage decreased significantly in all treatments with the advancement of storage time (Table 2). On the day of the experimental setup, the juice recovery percentage was found to be $58.24 \%$. The juice recovery percentage was not significant between treatments for the storage period time of 5 days and 10 days. At 30 days after storage, maximum juice recovery percentage was observed in wax coating with $0.5 \%$ lemongrass (42.86\%), which was statistically at par with the wax coating with $0.5 \%$ eucalyptus $(42.81 \%)$. The lowest juice recovery percentage was seen in control fruits $(33.49 \%)$.

Table 2: Effect of postharvest treatments on juice recovery percentage of sweet orange fruits

\begin{tabular}{|l|l|l|l|l|l|l|l|}
\hline \multirow{2}{*}{ Treatments } & \multicolumn{7}{|c|}{ Per cent juice content of fruits on days indicated } \\
\cline { 2 - 8 } & $\mathbf{1}$ & $\mathbf{5}$ & $\mathbf{1 0}$ & $\mathbf{1 5}$ & $\mathbf{2 0}$ & $\mathbf{2 5}$ & $\mathbf{3 0}$ \\
\hline T1 & 58.24 & 57.04 & 50.17 & $47.04^{\mathrm{abc}}$ & $45.05^{\mathrm{c}}$ & $43.82^{\mathrm{bc}}$ & $41.45^{\mathrm{cd}}$ \\
\hline T2 & 58.24 & 56.95 & 49.56 & $47.81^{\mathrm{a}}$ & $46.21^{\mathrm{a}}$ & $44.10^{\mathrm{ab}}$ & $42.86^{\mathrm{a}}$ \\
\hline T3 & 58.24 & 56.73 & 49.60 & $46.67^{\mathrm{bc}}$ & $45.30^{\mathrm{bc}}$ & $43.69^{\mathrm{c}}$ & $41.18^{\mathrm{c}}$ \\
\hline T4 & 58.24 & 57.38 & 51.70 & $47.92^{\mathrm{a}}$ & $45.93^{\mathrm{ab}}$ & $44.25^{\mathrm{a}}$ & $41.63^{\mathrm{c}}$ \\
\hline T5 & 58.24 & 57.10 & 50.60 & $47.60^{\mathrm{ab}}$ & $45.46^{\mathrm{abc}}$ & $43.64^{\mathrm{c}}$ & $42.29^{\mathrm{b}}$ \\
\hline T6 & 58.24 & 57.23 & 50.82 & $47.55^{\mathrm{ab}}$ & $46.16^{\mathrm{a}}$ & $44.10^{\mathrm{ab}}$ & $42.81^{\mathrm{a}}$ \\
\hline T7 & 58.24 & 56.98 & 49.80 & $46.42^{\mathrm{c}}$ & $43.50^{\mathrm{d}}$ & $39.71^{\mathrm{e}}$ & $38.50^{\mathrm{e}}$ \\
\hline T8 & 58.24 & 57.20 & 51.20 & $46.12^{\mathrm{c}}$ & $44.10^{\mathrm{d}}$ & $42.02^{\mathrm{d}}$ & $41.16^{\mathrm{d}}$ \\
\hline T9 & 58.24 & 56.59 & 50.63 & $46.08^{\mathrm{c}}$ & $40.67^{\mathrm{e}}$ & $36.10^{\mathrm{f}}$ & $33.49^{\mathrm{f}}$ \\
\hline LSD & & $0.60^{\mathrm{ns}}$ & $0.85^{\mathrm{ns}}$ & $1.06^{* *}$ & $0.70^{* * *}$ & $0.31^{* * *}$ & $0.28^{* * *}$ \\
\hline CV & 0.73 & 1.47 & 1.55 & 1.08 & 0.51 & 0.47 \\
\hline Mean & & 57.01 & 50.45 & 47.02 & 44.71 & 42.38 & 40.59 \\
\hline
\end{tabular}

LSD $=$ Least Significant Difference, $\mathrm{CV}=$ Coefficient of Variation, Means within the column followed by same letters do not differ significantly at $5 \%$ level of significance by DMRT, Significance codes ***at $0.001, * *$ at $0.01, *$ at 0.05

\section{Fruit firmness}

The fruit firmness decreased with the advancement of the storage period in all treatments (Fig. 1). On the day of the experimental setup, the fruit firmness was found to be $5.35 \mathrm{~kg} / \mathrm{cm}^{2}$. On the $30^{\text {th }}$ day after storage, firmness was highest for wax with $0.5 \%$ eucalyptus $\left(3.50 \mathrm{~kg} / \mathrm{cm}^{2}\right)$ and lowest in control $(2.25$ $\mathrm{kg} / \mathrm{cm}^{2}$ ) followed by wax with $0.1 \%$ carbendazim $\left(2.75 \mathrm{~kg} / \mathrm{cm}^{2}\right)$. 


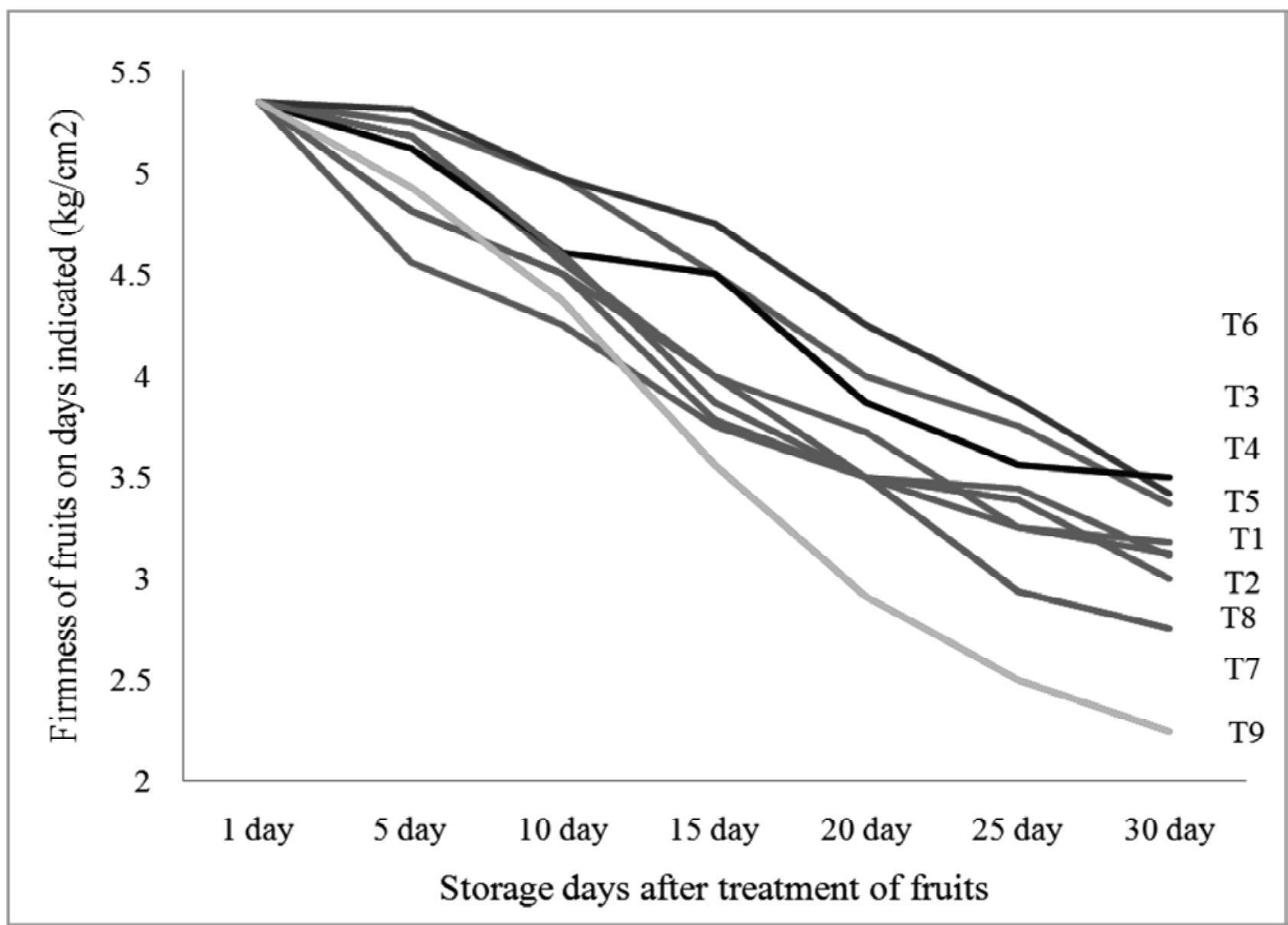

Fig.1 : Effect of postharvest treatments on firmness of sweet orange fruits

\section{Total soluble solids (TSS)}

Total soluble solid directly influences the taste of sweet orange. The TSS of fruit on the first day of storage was $11.20^{\circ}$ Brix. TSS increased with increment in the storage period in all treatments from 10 days onwards (Table 3 ). However, TSS was found to decrease on the $5^{\text {th }}$ day of storage for the treatment wax with mentha. There was no significant difference between treatments on the $5^{\text {th }}$ and $10^{\text {th }}$ day of storage. The highest TSS was observed in control fruits $\left(12.41^{\circ}\right.$ Brix) followed by wax with $0.1 \%$ carbendazim $\left(12.28^{\circ}\right.$ Brix $)$ while the lowest TSS was observed in wax with $0.5 \%$ lemongrass $\left(11.97^{\circ} \mathrm{Brix}\right)$ at $30^{\text {th }}$ day after storage.

\section{Titratable Acidity (TA)}

The titratable acidity is an important factor that is directly related to organic acid present in the fruit and also determines the quality of sweet orange. The TA was 1.12 on the first day of the experiment. The effect was significant only after the $10^{\text {th }}$ day of treatment. There was a gradual decrease in TA of sweet orange along with the storage time. At the end of storage life i.e. $30^{\text {th }}$ day, TA was highest for wax with $0.5 \%$ lemongrass $(0.94 \%)$, which was statistically at par to wax with $0.1 \%$ lemongrass $(0.92 \%)$ and $0.5 \%$ carbendazim $(0.91 \%)$. The lowest TA was shown by control $(0.72 \%)$ at the end of storage life (Table 4). 
Table 3: Effect of postharvest treatments on TSS of sweet orange fruits

\begin{tabular}{|l|c|c|c|c|c|c|c|}
\hline \multirow{2}{*}{ Treatments } & \multicolumn{7}{|c|}{ TSS of fruits on days indicated } \\
\cline { 2 - 8 } & $\mathbf{1}$ & $\mathbf{5}$ & $\mathbf{1 0}$ & $\mathbf{1 5}$ & $\mathbf{2 0}$ & $\mathbf{2 5}$ & $\mathbf{3 0}$ \\
\hline T1 & 11.20 & 11.25 & 11.30 & $11.40^{\text {bcd }}$ & $11.69^{\mathrm{b}}$ & $11.82^{\mathrm{e}}$ & $12.21^{\mathrm{c}}$ \\
\hline T2 & 11.20 & 11.25 & 11.30 & $11.40^{\mathrm{bcd}}$ & $11.60^{\mathrm{c}}$ & $11.72^{\mathrm{f}}$ & $11.97^{\mathrm{d}}$ \\
\hline T3 & 11.20 & 11.00 & 11.20 & $11.41^{\mathrm{abc}}$ & $11.65^{\mathrm{b}}$ & $11.97^{\mathrm{bc}}$ & $12.22^{\mathrm{bc}}$ \\
\hline T4 & 11.20 & 11.00 & 11.30 & $11.45^{\mathrm{ab}}$ & $11.78^{\mathrm{a}}$ & $11.8^{\mathrm{e}}$ & $12.19^{\mathrm{c}}$ \\
\hline T5 & 11.20 & 11.25 & 11.30 & $11.37^{\mathrm{cd}}$ & $11.65^{\mathrm{bc}}$ & $11.9^{\mathrm{d}}$ & $12.20^{\mathrm{c}}$ \\
\hline T6 & 11.20 & 11.25 & 11.30 & $11.40^{\mathrm{bcd}}$ & $11.61^{\mathrm{c}}$ & $11.8^{\mathrm{d}}$ & $12.10^{\mathrm{d}}$ \\
\hline T7 & 11.20 & 11.20 & 11.25 & $11.34^{\mathrm{d}}$ & $11.65^{\mathrm{bc}}$ & $12.02^{\mathrm{b}}$ & $12.28^{\mathrm{b}}$ \\
\hline T8 & 11.20 & 11.25 & 11.30 & $11.37^{\mathrm{cd}}$ & $11.61^{\mathrm{c}}$ & $11.95^{\mathrm{c}}$ & $12.19^{\mathrm{c}}$ \\
\hline T9 & 11.20 & 11.25 & 11.30 & $11.47^{\mathrm{a}}$ & $11.78^{\mathrm{a}}$ & $12.19^{\mathrm{a}}$ & $12.41^{\mathrm{a}}$ \\
\hline LSD & & $0.20^{\mathrm{ns}}$ & $0.08^{\mathrm{ns}}$ & $0.06^{* *}$ & $0.04^{* * *}$ & $0.04^{* * *}$ & $0.06^{* * *}$ \\
\hline CV & & 1.82 & 0.53 & 0.37 & 0.27 & 0.23 & 0.35 \\
\hline Mean & & 11.18 & 11.28 & 11.40 & 11.66 & 11.91 & 12.20 \\
\hline
\end{tabular}

LSD $=$ Least Significant Difference, $\mathrm{CV}=$ Coefficient of Variation, Means within the column followed by same letters do not differ significantly at $5 \%$ level of significance by DMRT, Significance codes ***at $0.001, * *$ at $0.01, *$ at 0.05 .

Table 4: Effect of postharvest treatments on TA of sweet orange fruits

\begin{tabular}{|l|c|c|c|c|c|c|c|}
\hline \multirow{2}{*}{ Treatments } & \multicolumn{7}{|c|}{ TA on days indicated } \\
\cline { 2 - 8 } & $\mathbf{1}$ & $\mathbf{5}$ & $\mathbf{1 0}$ & $\mathbf{1 5}$ & $\mathbf{2 0}$ & $\mathbf{2 5}$ & $\mathbf{3 0}$ \\
\hline T1 & 1.12 & 1.05 & $1.03^{\mathrm{bc}}$ & $1.02^{\mathrm{ab}}$ & $0.95^{\mathrm{ab}}$ & $0.93^{\mathrm{ab}}$ & $0.92^{\mathrm{ab}}$ \\
\hline T2 & 1.12 & 1.04 & $1.05^{\mathrm{b}}$ & $1.03^{\mathrm{ab}}$ & $0.99^{\mathrm{a}}$ & $0.95^{\mathrm{a}}$ & $0.94^{\mathrm{a}}$ \\
\hline T3 & 1.12 & 1.03 & $0.95^{\mathrm{de}}$ & $0.92^{\mathrm{de}}$ & $0.91^{\mathrm{c}}$ & $0.84^{\mathrm{d}}$ & $0.84^{\mathrm{d}}$ \\
\hline T4 & 1.12 & 1.04 & $0.99^{\mathrm{d}}$ & $0.94^{\mathrm{d}}$ & $0.93^{\mathrm{bc}}$ & $0.88^{\mathrm{c}}$ & $0.82^{\mathrm{d}}$ \\
\hline T5 & 1.12 & 1.05 & $0.95^{\mathrm{de}}$ & $0.9^{\mathrm{e}}$ & $0.86^{\mathrm{d}}$ & $0.85^{\mathrm{d}}$ & $0.82^{\mathrm{d}}$ \\
\hline T6 & 1.12 & 1.02 & $1.04^{\mathrm{bc}}$ & $0.98^{\mathrm{c}}$ & $0.95^{\mathrm{abc}}$ & $0.91^{\mathrm{b}}$ & $0.86^{\mathrm{cd}}$ \\
\hline T7 & 1.12 & 1.02 & $1.05^{\mathrm{bc}}$ & $1.01^{\mathrm{b}}$ & $0.96^{\mathrm{ab}}$ & $0.93^{\mathrm{ab}}$ & $0.87^{\mathrm{bcd}}$ \\
\hline T8 & 1.12 & 1.03 & $1.08^{\mathrm{a}}$ & $1.04^{\mathrm{a}}$ & $0.97^{\mathrm{ab}}$ & $0.93^{\mathrm{ab}}$ & $0.91^{\mathrm{abc}}$ \\
\hline T9 & 1.12 & 1.03 & $0.89^{\mathrm{e}}$ & $0.85^{\mathrm{f}}$ & $0.76^{\mathrm{e}}$ & $0.74^{\mathrm{e}}$ & $0.72^{\mathrm{e}}$ \\
\hline LSD & & $0.00^{\text {ns }}$ & $0.12^{* *}$ & $0.01^{* * *}$ & $0.03^{* * *}$ & $0.02^{* * *}$ & $0.05^{* * *}$ \\
\hline CV & & 4.86 & 1.85 & 1.30 & 2.75 & 2.01 & 4.00 \\
\hline Mean & & 1.03 & 1.00 & 0.96 & 0.92 & 0.88 & 0.85 \\
\hline
\end{tabular}

LSD $=$ Least Significant Difference, $\mathrm{CV}=$ Coefficient of Variation, Means within the column followed by same letters don not differ significantly at $5 \%$ level of significance by DMRT, Significance codes ***at $0.001, * *$ at $0.01, *$ at 0.05 . 


\section{Ascorbic Acid (Vitamin C) content}

Vitamin $\mathrm{C}$ content is an important nutritive parameter in citrus fruits and it was decreased gradually during the advancement of storage days (Fig. 2). On the first day of storage, the vitamin $\mathrm{C}$ content was measured to be $40 \mathrm{mg} / 100 \mathrm{ml}$ of orange juice. On the $30^{\text {th }}$ day, the highest vitamin $\mathrm{C}$ was found in fruits coated with wax and $0.5 \%$ eucalyptus $(30.31 \mathrm{mg} / 100 \mathrm{ml})$, followed by wax with $0.5 \%$ mentha $(29.50 \mathrm{mg} / 100 \mathrm{ml})$ and $0.1 \%$ mentha $(29.18 \mathrm{mg} / 100 \mathrm{ml})$, while the lowest vitamin C was observed in control fruits $(24.5 \mathrm{mg} / 100 \mathrm{ml})$.

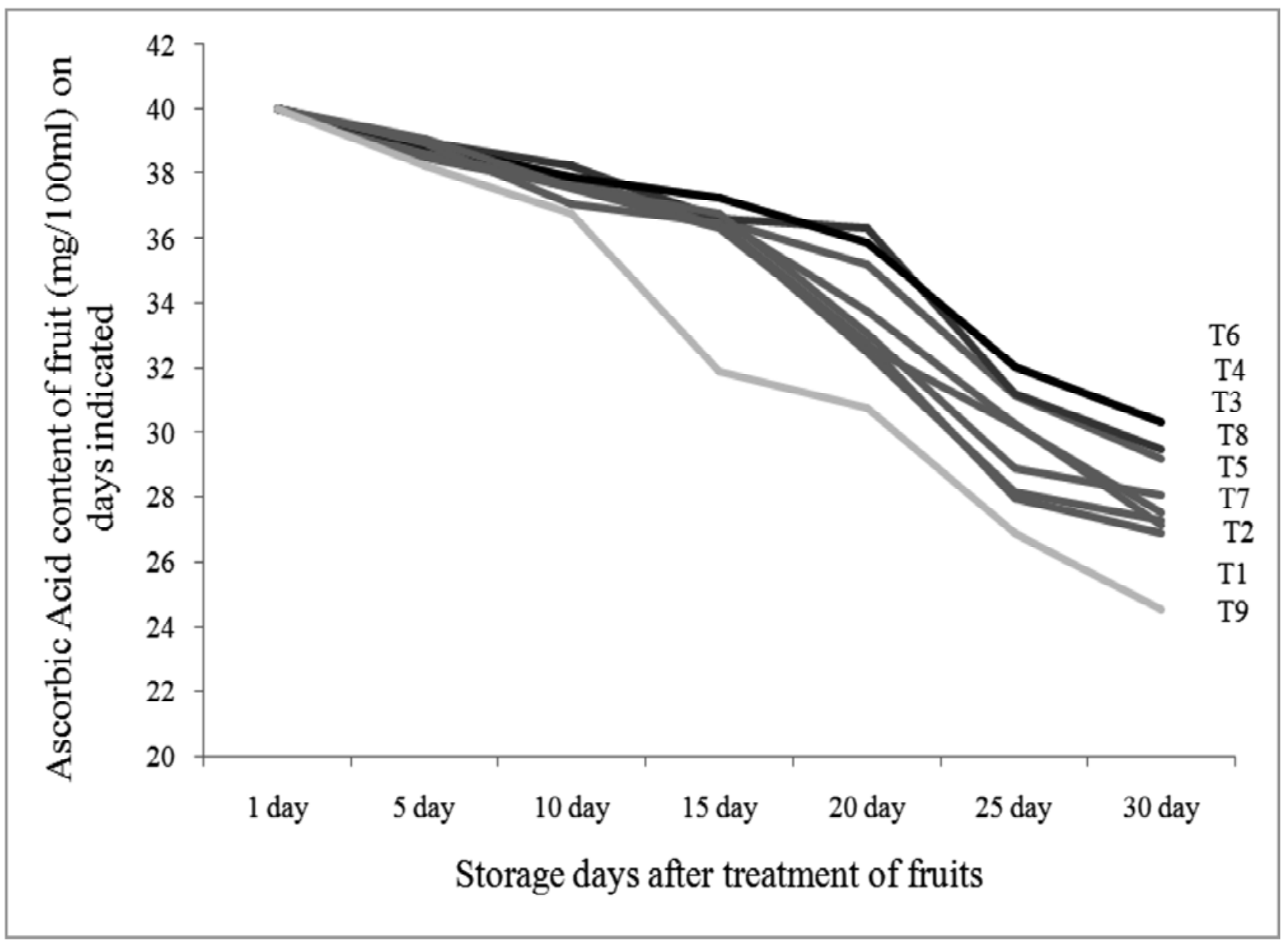

Fig. 2: Effect of postharvest treatments on Ascorbic Acid content of sweet orange fruits

\section{Disease severity index}

The disease occurrence in sweet orange was increased with the storage days (Table 5). The green mold ( $P$. digitatum) was confirmed through the lab culture of a pathogen. The fruits treated with essential oils and fungicide were found to be more resistant to postharvest fungal diseases. On the $30^{\text {th }}$ day of storage, almost all treatments exhibited noticeable disease occurrence, control being the highest infected $(0.372 \%)$ followed by wax with $0.1 \%$ mentha $(0.180 \%)$. The treatment of wax with $0.5 \%$ carbendazim $(0.004 \%)$ was most effective against fungal pathogen and wax with $0.5 \%$ eucalyptus oil $(0.025 \%)$ and $0.5 \%$ lemongrass oil $(0.025 \%)$ being the most effective essential oils. 
Table 5: Effect of postharvest treatments on disease severity index in sweet orange fruits

\begin{tabular}{|l|l|l|l|l|l|l|l|}
\hline \multirow{2}{*}{ Treatments } & \multicolumn{7}{|c|}{ Disease severity index of fruits on days indicated } \\
\cline { 2 - 8 } & $\mathbf{1}$ & $\mathbf{5}$ & $\mathbf{1 0}$ & $\mathbf{1 5}$ & $\mathbf{2 0}$ & $\mathbf{2 5}$ & $\mathbf{3 0}$ \\
\hline T1 & 0.00 & 0.00 & 0.00 & 0.00 & $0.025^{\text {bc }}$ & $0.075^{\mathrm{b}}$ & $0.123^{\mathrm{b}}$ \\
\hline T2 & 0.00 & 0.00 & 0.00 & 0.00 & $0.004^{\text {de }}$ & $0.012^{\text {cd }}$ & $0.025^{\text {d }}$ \\
\hline T3 & 0.00 & 0.00 & $0.004^{\mathrm{b}}$ & $0.012^{\mathrm{b}}$ & $0.038^{\mathrm{b}}$ & $0.075^{\mathrm{b}}$ & $0.180^{\mathrm{b}}$ \\
\hline T4 & 0.00 & 0.00 & 0.00 & 0.00 & $0.017^{\text {cd }}$ & $0.046^{\text {bc }}$ & $0.114^{\text {bc }}$ \\
\hline T5 & 0.00 & 0.00 & 0.00 & $0.012^{\mathrm{b}}$ & $0.038^{\mathrm{b}}$ & $0.058^{\mathrm{b}}$ & $0.114^{\text {bc }}$ \\
\hline T6 & 0.00 & 0.00 & 0.00 & 0.00 & $0.008^{\text {de }}$ & $0.012^{\text {cd }}$ & $0.025^{\text {d }}$ \\
\hline T7 & 0.00 & 0.00 & 0.00 & 0.00 & 0.00 & 0.000 & $0.033^{\text {cd }}$ \\
\hline T8 & 0.00 & 0.00 & 0.00 & 0.00 & 0.00 & 0.000 & $0.004^{\text {d }}$ \\
\hline T9 & 0.00 & 0.00 & $0.042^{\mathrm{a}}$ & $0.054^{\mathrm{a}}$ & $0.096^{\mathrm{a}}$ & $0.207^{\mathrm{a}}$ & $0.372^{\mathrm{a}}$ \\
\hline LSD & & $0.009^{* * *}$ & $0.013^{* * *}$ & $0.013^{* * *}$ & $0.038^{* * *}$ & $0.080^{* * *}$ \\
\hline CV & & 121.76 & 105.94 & 35.646 & 48.471 & 50.13 \\
\hline Mean & & & 0.005 & 0.008 & 0.025 & 0.054 & 0.110 \\
\hline
\end{tabular}

LSD = Least Significant Difference, CV= Coefficient of Variation, Means within the column followed by same letters do not differ significantly at $5 \%$ level of significance by DMRT, Significance codes ***at $0.001, * *$ at $0.01, *$ at 0.05 .

\section{Shelf life}

The wax treatment with carbendazim and essential oils had a significantly better shelf life as compared to the control treatment (Table 6). Wax with $0.5 \%$ carbendazim (28.25 days) being the highest and significantly better than other treatments. It was followed by wax with $0.1 \%$ carbendazim $(25.75$ days), wax with $0.5 \%$ lemongrass oil (20.00 days) and wax with $0.5 \%$ eucalyptus oil (19.75 days). The control fruits ( 8.25 days) were observed to have the lowest shelf life.

\section{Discussion}

A significantly lower juice recovery percentage of control fruits might be due to the fact that the essential oils act as a barrier which checks the loss of moisture from the fruit surface due to the clogging of natural openings (Castillo et al., 2014). Additionally, the lower incidence of disease in essential oils and fungicides treated fruit ensure lower metabolism, which might have contributed to a higher juice recovery percentage. The present finding was supported by (Bisen et al., 2012). The control fruit also had a wax coating and the transpiration process was very slow, so there was an insignificant difference in juice recovery percentage between treatments before $15^{\text {th }}$ day of storage. The moisture
Table 6: Effect of postharvest treatments on shelf life in sweet orange fruits

\begin{tabular}{|l|c|}
\hline Treatments & Shelf life \\
\hline T1 & $17.25^{\mathrm{d}}$ \\
\hline T2 & $20.00^{\mathrm{c}}$ \\
\hline T3 & $10.00^{\mathrm{f}}$ \\
\hline T4 & $16.75^{\mathrm{d}}$ \\
\hline T5 & $14.25^{\mathrm{e}}$ \\
\hline T6 & $19.75^{\mathrm{c}}$ \\
\hline T7 & $25.75^{\mathrm{b}}$ \\
\hline T8 & $28.25^{\mathrm{a}}$ \\
\hline T9 & $8.25^{\mathrm{g}}$ \\
\hline LSD & $0.92^{* * *}$ \\
\hline CV & 3.55 \\
\hline Mean & 17.80 \\
\hline
\end{tabular}

LSD $=$ Least Significant Difference, CV $=$ Coefficient of Variation, Means within the column followed by same letters don not differ significantly at $5 \%$ level of significance by DMRT, Significance codes $* * *$ at $0.001, * *$ at $0.01, *$ at 0.05 . 
loss was found significantly lower in fruit treated with essential oil enriched coatings (Du Plooy et al., 2009; D Antunes et al., 2012; Castillo et al., 2014).

In general, coating formulations that minimize weight loss are also better at maintaining firmness, since this attribute is highly influenced by water content. Fruit firmness decreased gradually and significantly along with increasing storage period in all treatments. The decelerated damage may be due to the anti-microbial properties of essential oils. The lowest fruit firmness in control fruit might be due to the rapid degradation of cell walls due to the action of wall-degrading enzymes such as pectinesterase, pectinmethylesterase and polygalacturonase which are produced by fungi. Essential oil amended coating maintains cell wall carbohydrate metabolism during storage which is related to decreased susceptibility to infection by fungal pathogen and therefore improves quality. The essentials oils together with commercial wax coating maintain the organoleptic integrity along with firmness as mentioned by Jhalegar et al. (2014). The essential oils affect the portioning of the lipids of the plasma membrane and changing of its integrity, permeability and inorganic ion equilibrium due to their hydrophobic nature (Lambert et al., 2001) which might be the reasons for greater firmness in the fruits treated essential oils. The present findings were supported by Chafer et al. (2012) on the firmness of Navel Powell orange and Castillo et al. (2014) on lemon fruits.

The gradual increase of TSS with extending of the storage period might be attributed to concentrated juice content results from dehydration and hydrolysis of polysaccharides. The increased respiration rate due to microbial spoilage, degradation of fruits and increased ethylene production ultimately increased the TSS during ripening and senescence which might be the reason for slightly higher TSS in control fruits as compared to other treatments. The present result was in agreement with the findings of Chafer et al. (2012) on Navel Powell orange and Castillo et al. (2014) on lemon and Tao et al. (2014) on Satusma mandarin, as the essential oils did not show a significant effect on TSS. The present finding was also inconsistent with Asghari et al. (2009) who reported insignificant results in TSS while using cumin essential oil on strawberry.

The decrease in titratable acidity with storage is due to the oxidation of organic acids and further utilization in the metabolic process in the fruits (Hafeez et al.,2012). A gradual declining trend in titratable acidity content of fruit during storage for any treatment was observed by Ansari and Feridoon (2007) and Obenland et al. (2008) in citrus. The decreased in titratable acidity of fruits during storage could be due to the consumption of organic acids in the respiration process as stated by Zokaei et al. (2006) and Ishaq et al. (2009). Similarly, Baiea (2013) on Washington Navel orange detected a decrease in the acidity of fruits during storage. Fruits treated with essential oils showed higher retention of titratable acidity during the storage period which might due to delayed in physiological ageing and alteration in metabolism. The present results are in line with Mahajan et al. (2010) suggesting that organic acids were used in the respiratory process. The higher titratable acidity in wax with lemongrass treatment is aligned with the finding of Fatemi et al. (2012) who reported that the thymol oil delayed the changes in titratable acidity of Valencia orange. The present finding was also supported by Jhalegar et al. (2014) on Kinnow mandarin. Abd El wahab et al. (2014) also reported bergamot oil delayed the changes in titratable acidity during cold storage of Crimson seedless grape.

Adisa (1986) stated that vitamin C decreased over time in storage which is similar to the experimental outcome. The decreased in ascorbic acid content of fruits during storage could be due to the conversion of dehydroascorbic to diketogulonic acid by oxidation as reported by Ishaq et al. (2009). Under stress, such as a pathogen or chemical exposure, ascorbate oxidase levels were increased, which decreased the level of vitamin C (Loewus and Loewus, 1983; Loewus et al.,1987). The maximum retention of vitamin $C$ was observed with essential oils treatments due to the antioxidant property of essential oils which prevent ascorbic acid from oxidation (Shao et al., 2013). The result was similar to Lin et al. (2011) who found that the decrease in vitamin $\mathrm{C}$ level was associated with a reduced capacity of preventing oxidative damage which is triggered by the incidence of physiological disorders during storage. The degradation of vitamin $\mathrm{C}$ was highest in control fruits which might be due to fruit senescence accompanied by rapid respiration, ethylene production and decay. These results are similar to those reported on the effect of thyme and 
clove oil in maintaining ascorbic acid as for orange (Zeng et al., 2012; Baiea and Ei-Badawy, 2013).

The result was similar to the report of Abd-ElKhair and Hafez (2006), as they reported the lemongrass and eucalyptus essential oils significantly reduced the incidence of fungus $P$. digitatum in Washington navel orange during storage. Abdolahi et al., (2010) and Al-Samarrai et al., (2013) found various plant extracts including lemongrass extract could inhibit the mycelial growth of pathogenic fungus $P$. digitatum. The phenolic compounds and their derivatives of essential oils altered the microbial cell permeability by interacting with membrane proteins which would cause deformation in cell structure and function and permit the loss of macromolecules from their body (Fung et al., 1997; Rattanapitigorn et al., 2006) which might be the reasons of lower microbial growth in the essential oils treated fruits compare to control. Amit and Malik (2010) indicated that the vapoursof lemongrass oil damaged the cell membrane mainly due to membrane deformation. However, the variation in the antifungal effect of the essential oils depends on the solubility and capacity to interact with the cytoplasmic membrane (Tripathi and Shukla, 2007). The efficacy of lemongrass was also found superior by Jhalegar et al. (2015). Similar results were reported by Du Plooy et al. (2009), Fan et al. (2014), Jhalegar et al. (2014) and GandarillaPacheco et al. (2020) in citrus fruits.

Table 7: Summary of studies on the effect of essential oils on major post-harvest pathogens of citrus

\begin{tabular}{|l|l|l|l|}
\hline Fruit & Target pathogen & Essential oils & References \\
\hline Orange cv. Tomango & P. digitatum & Mentha oil & Du Plooy et al. (2009) \\
\hline Orange, Lime & P. italicum & Mentha oil & Tripathi et al. (2004) \\
\hline Washington Navel Orange & P. digitatum & $\begin{array}{l}\text { Lemongrass oil, } \\
\text { Eucalyptus oil }\end{array}$ & $\begin{array}{l}\text { Abd-El-Khair and Hafez } \\
\text { (2006) }\end{array}$ \\
\hline Valencia Orange & G. citri-aurantii & Lemongrass oil & Regnier et al. (2014) \\
\hline Kinnow Mandarin & P. digitatum, P. italicum & Eucalyptus oil & Jhalegar et al. (2014) \\
\hline Kinnow Mandarin & $\begin{array}{l}\text { P. italicum and } \\
\text { P. digitatum }\end{array}$ & $\begin{array}{l}\text { Lemongrass oil, } \\
\text { Eucalyptus oil }\end{array}$ & Jhalegar et al. (2015) \\
\hline
\end{tabular}

The wax with $0.5 \%$ carbendazim with its prominent disease resistance had the longest storability. The superiority of shelf life of $0.5 \%$ lemongrass and eucalyptus oils treated fruits might be due to the antifungal properties of essential oils (Tzortzakis and Economakis, 2007; Jhalegar et al., 2014; Jhalegar et al., 2015). In addition to this, postharvest decay is positively correlated with ethylene production and respiration rate which were found to be decreased by the application of essential oils (Jhalegar et al., 2014; Jhalegar et al., 2015). The present result was inconsistent with Tripathi et al. (2004) and Tavakoli et al. (2019).
The green mold is the major postharvest pathogen in sweet orange. The chemical fungicides have been found effective against such pathogens, but the health hazard of such pesticides is alarmingly high. The use of essential oils as an alternative for chemicals can be an environment friendly technique for prevention of the health hazards. The shelf life of sweet orange can be extended by infusing wax with carbendazim or essential oils. But the superiority of essential oils especially wax with $0.5 \%$ eucalyptus oil and $0.5 \%$ lemongrass in qualitative parameters as well as in consumer's preferences, organic requirements and environmental aspects make them a better alternative. 


\section{REFERENCES}

Abd El Wahab, W.A., Abd El Wahab S.M., Kamel, O.T. 2014. Using safe alternatives for controlling postharvest decay, maintaining quality of Crimson seedless grape. World Applied Sciences Journal, 31(7):1345-1357.

Abd-El-Khair, H. and El-Mougy, N. S. 2003. Field biological approach under organic cultivation conditions for controlling garlic black mould disease infection during storage. Egypt J Appl Sci. 18:50-69.

Abd-El-Khair, H. and Hafez O. 2006. Effect of aqueous extracts of some medicinal plants in controlling the green mould disease and improvement of stored" Washington" navel orange quality. J Appl Sci Res. 2:664-674.

Abdolahi, A., Hassani, A., Ghosta, Y., Bernousi, I. and Meshkatalsadat, M. 2010. Study on the potential use of essential oils for decay control and quality preservation of Tabarzeh table grape. Journal of Plant Protection Research, 50(1): 45-52.

Adisa, V.A. 1986. The influence of molds and some storage factors on the ascorbic acid content of orange and pineapple fruits. Food Chemistry, 22(2):139-146.

Alam, A., Tripathi, A., Sharma, V. and Sharma, N. 2017. Essential oils: a novel consumer and ecofriendly approach to combat postharvest phytopathogens. Journal of Advances in Biology \& Biotechnology, 11(1): 1-16.

Al-Samarrai, G.F., Singh, H. and Syarhabil, M. 2013. Extracts some plants on controlling green mold of orange and on postharvest quality parameters. World Applied Sciences Journal, 22(4):564-570.

Ameziane, N., Boubaker, H., Boudyach, H., Msanda, F., Jilal, A. and Benaoumar, A.A. 2007. Antifungal activity of Moroccan plants against citrus fruit pathogens. Agronomy for Sustainable Development. 27(3):273-277.

Amit, K.T. and Malik, A. 2010. Liquid and vapourphase antifungal activities of selected essential oils against Candida albicans: microscopic observations and chemical characterization of
Cymbopogon citratus. BMC Complement Altern. Med., 10: 1-11.

AOAC. 2005. Official Methods of Analysis. Association of Official Analytical Chemists, Washington DC, USA.

Ansari, N.A. and Feridoon, H. 2007. Postharvest application of hot water, fungicide and waxing on the shelf life of valencia and local oranges of siavarz. Asian Journal of Plant Sciences, 6(2):314-319.

Asghari, M.A., Mostoufi, Y., Shoeyhi, S. and Fatahi, M. 2009. Effect of cumin essential oil on postharvest decay and some quality factors of strawberry. Journal of Medicinal Plants, 8: 25-43.

Bagamboula, C.F., Uyttendaele, M. and Debevere, J. 2004. Inhibitory effect of thyme and basil essential oils, carvacrol, thymol, estragol, linalool and p-cymene towards Shigella sonnei and $S$. flexneri. Food microbiology, 21(1):33-42.

Baiea, M.H. and El-Badawy, H.E. 2013. Response of Washington navel orange to thyme and clove oils as natural postharvest treatments under cold storage conditions. Journal of Applied Sciences Research, 9(7):4335-4344.

Barnett, H.L. and Hunter, B.B. 1998. Illustrated genera of imperfect fungi. 4th Edn. American Phytopathological Society (APS Press). MacMillan Publishing Co. New York, USA. p. 1-97.

Berk Z. 2016. Citrus fruit processing. In: Z. Berk (Ed.). San Diego: Academic Press. p. 95-105.

Bisen, 2012 A., Pandey, S.K. and Patel, N. 2012. Effect of skin coatings on prolonging shelf life of kagzi lime fruits (Citrus aurantifolia Swingle). Journal of Food Science and Technology, 49(6):753-9.

Bridson, E.Y.1995. The Oxide Manual. $7^{\text {th }}$ Edn. Unipath Limited, Wade Koad, Basingstoke Hamphire, RG 248 PW, England. p. 2-187.

Castillo, S., Pérez-Alfonso, C.O., Martínez-Romero, D., Guillén, F., Serrano, M. and Valero, D. 2014. The essential oils thymol and carvacrol 
applied in the packing lines avoid lemon spoilage and maintain quality during storage. Food Control, 35(1):132-136.

Cháfer, M., Sánchez González, L., González Martínez, C. and Chiralt A. 2012. Fungal decay and shelf life of oranges coated with chitosan and bergamot, thyme, and tea tree essential oils. Journal of Food Science, 77(8): E182-E187.

D Antunes, M., M Gago, C., M Cavaco, A. and G Miguel, M. 2012. Edible coatings enriched with essential oils and their compounds for fresh and fresh-cut fruit. Recent Patents on Food, Nutrition \& Agriculture, 4(2): 114-122.

Danderson, M. 1986. Omega*(prochloraz), a fungicide for post-harvest control of anthracnose, the Dothiorella/Colletotrichum complex and stemend rot in avocados. South African Avocado Growers' Association Yearbook, 9:27-30.

Du Plooy, W., Regnier, T. and Combrinck S. 2009. Essential oil amended coatings as alternatives to synthetic fungicides in citrus postharvest management. Postharvest Biology and Technology, 53(3):117-22.

El-Otmani, M., Ait-Oubahou, A. and Zacarías, L. 2011. Citrus spp.: orange, mandarin, tangerine, clementine, grapefruit, pomelo, lemon and lime.In: Postharvest biology and technology of tropical and subtropical fruits. Cambridge, GB: Woodhead Publishing. p. 437-514.

Fan, F., Tao, N., Jia, L. and He, X. 2014. Use of citral incorporated in postharvest wax of citrus fruit as a botanical fungicide against Penicillium digitatum. Postharvest Biology and technology, 90:52-5.

Fatemi, S., Jafarpour, M. and Eghbalsaied, S. 2012. Study of the effect of Thymus vulgaris and hot water treatment on storage life of orange (Citrus sinensis CV. Valencia). Journal of Medicinal Plants Research, 6(6):968-971.

Fogliata, G.M., Torres Leal, G.J. and Ploper, L.D. 2000. Detection of imazalil-resistant strains of Penicillium digitatum Sacc. in citrus packinghouses of Tucumán Province (Argentina) and their behavior against currently employed and alternative fungicides.
Revista industrial y agrícola de Tucumán, 77(2):71-5.

Fung, D.Y., Taylor, S.U. and Kahan, J. 1977. Effects of butylated hydroxyanisole (BHA) and butylated hydroxytoluene (BHT) on growth and aflatoxin production of Aspergillus flavus. Journal of Food Safety, 1(1):39-51.

Gandarilla-Pacheco, F.L., Torres-Caraballo, S., de Luna-Santillana, E.J., Quintero-Zapata, I. and Arroyo-González, N. 2020. Inhibitory effect of essential oils on the mycelial growth of Penicillium digitatum (pers.) sacc. isolated from sweet orange (Citrus sinensis osbeck). Agrociencia, 1:209-225.

Hafeez, O., Malik, A.U., Khan, A.S., Rehman, A. and Javaid, Q.A. 2012. Impact of different packaging types and low temperature shipping durations on fruit quality and marketability of Pakistani mangoes. International Journal of Agriculture and Biology, 14(1):47-54.

Hao, W., Li, H., Hu, M., Yang, L. and Rizwan-ul-Haq, M. 2011. Integrated control of citrus green and blue mold and sour rot by Bacillus amyloliquefaciens in combination with tea saponin. Postharvest Biology and Technology, 59(3):316-23.

Hendel, N., Larous, L. and Belbey, L. 2016. Antioxidant activity of rosemary (Rosmarinus officinalis L.) and its in vitro inhibitory effect on Penicillium digitatum. International Food Research Journal, 23(4):1725.

Ishaq, S., Rathore, H.A., Majeed, S., Awan, S. and Zulfiqar-Ali-Shah, S. 2009. The studies on the physico-chemical and organoleptic characteristics of apricot (Prunus armeniaca L.) produced in Rawalakot, Azad Jammu and Kashmir during storage. Pakistan Journal of Nutrition, 8(6):856-860.

Ismail, M. and Zhang, J. 2004. Post-harvest citrus diseases and their control. Outlooks on Pest Management, 15(1):29-35.

Jhalegar, M.J., Sharma, R.R. and Singh, D. 2014. Antifungal efficacy of botanicals against major postharvest pathogens of Kinnow mandarin and their use to maintain postharvest quality. Fruits, 69(3):223-237. 
Jhalegar, M.J., Sharma, R.R. and Singh, D. 2015. In vitro and in vivo activity of essential oils against major postharvest pathogens of Kinnow (Citrus nobilis $\times$ C. deliciosa) mandarin. Journal of Food Science and Technology, 52(4):2229-2237.

Joshi, P., Ojha, B.P. and Kafle, A. 2020. Effect of different postharvest treatments on prolonging shelf life and maintaining quality of mandarin (Citrus reticulata Blanco.). Nepalese Horticulture, 14:1-8.

Kaini, B.R. 2013. Package of Practices for Junar production and post-harvest management. JICA-Nepal \& JCCU, Tinkune, Kathmandu, Nepal. p. 1-118.

Lambert, R.J., Skandamis, P.N., Coote, P.J. and Nychas, G.J. 2001. A study of the minimum inhibitory concentration and mode of action of oregano essential oil, thymol and carvacrol. Journal of Applied Microbiology, 91(3):453462.

Lin, L.L., Shi, Q.H., Wang, H.S., Qin, A.G. and Yu, X.C. 2011. Over-expression of tomato GDPMannose pyrophosphorylase (GMPase) in potato increases ascorbate content and delays plant senescence. Agricultural Sciences in China, 10(4):534-543.

Loewus, F.A. and Loewus, M.W. 1983. Myo-inositol: its biosynthesis and metabolism. Annual Review of Plant Physiology, 34(1):137-161.

Loewus, F.A., Loewus, M.W. and Seib, P.A. 1987. Biosynthesis and metabolism of ascorbic acid in plants. Critical Reviews in Plant Sciences, 5(1):101-119.

Mahajan, B.V., Singh, K. and Dhillon, W.S. 2010. Effect of 1-methylcyclopropene (1-MCP) on storage life and quality of pear fruits. Journal of Food Science and Technology, 47(3) : 351-354.

MOALD. 2020. Statistical Information on Nepalese Agriculture (2018/19). Ministry of Agriculture \& Livestock Development, Planning and Development Cooperation Coordination Division, Government of Nepal. Singhadurbar, Kathmandu, Nepal.
Obagwu, J. and Korsten, L. 2003. Integrated control of citrus green and blue molds using Bacillus subtilis in combination with sodium bicarbonate or hot water. Postharvest Biology and Technology, 28(1):1871-94.

Obenland, D., Collin, S., Sievert, J., Fjeld, K., Doctor, J. and Arpaia, M.L. 2008. Commercial packing and storage of navel oranges alters aroma volatiles and reduces flavor quality. Postharvest Biology and Technology, 47(2):159-167.

Papoutsis, K., Mathioudakis, M.M., Hasperué, J.H. and Ziogas, V. 2019. Non-chemical treatments for preventing the postharvest fungal rotting of citrus caused by Penicillium digitatum (green mold) and Penicillium italicum (blue mold). Trends in Food Science \& Technology, 86:479491.

Rattanapitigorn, P., Arakawa, M. and Tsuro, M. 2006. Vanillin enhances the antifungal effect of plant essential oils against Botrytis cinerea. International Journal of Aromatherapy, 16(34):193-198.

Regnier, T., Combrinck, S., Veldman, W. and Du Plooy, W. 2014. Application of essential oils as multi-target fungicides for the control of Geotrichum citri-aurantii and other postharvest pathogens of citrus. Industrial Crops and Products, 61:151-159.

Rokaya, P.R., Baral, D.R., Gautam, D.M., Shrestha, A.K. and Paudyal, K.P.2016. Effect of postharvest treatments on quality and shelf Life of mandarin (Citrus reticulata Blanco). American Journal of Plant Sciences, 7(7):1098-1105.

Rouabhi R. 2010. Introduction and toxicology of fungicides. INTECH Open Access Publisher.

Shao, X., Wang, H., Xu, F. and Cheng, S. 2013. Effects and possible mechanisms of tea tree oil vapor treatment on the main disease in postharvest strawberry fruit. Postharvest Biology and Technology, 77:94-101.

Singh, S., Singh, N., Kumar, V., Datta, S., Wani, A. B., Singh, D. and Singh, J. 2016. Toxicity, monitoring and biodegradation of the fungicide carbendazim. Environmental Chemistry Letters. 14(3): 317-329. 
Smilanick, J.L., Mansour, M.F., Gabler, F.M. and Goodwine, W.R. 2006. The effectiveness of pyrimethanil to inhibit germination of Penicillium digitatum and to control citrus green mold after harvest. Postharvest Biology and Technology. 42(1):75-85.

Smilanick, J.L., Mansour, M.F., Gabler, F.M. and Sorenson, D. 2008. Control of citrus postharvest green mold and sour rot by potassium sorbate combined with heat and fungicides. Postharvest Biology and Technology. 47(2):226-238.

Tao, N., Fan, F., Jia, L. and Zhang, M. 2014. Octanal incorporated in postharvest wax of Satsuma mandarin fruit as a botanical fungicide against Penicillium digitatum. Food Control. 45:56-61.

Tavakoli, S.A., Mirzaei, S., Rahimi, M. and Tavassolian, I. 2019. Assessment of peppermint, clove, cumin essential oils and silver nano particles on biochemical and shelf life of Citrus limon (L.). Indian Journal of Biochemistry and Biophysics (IJBB). 56(4): 269-275.

Tripathi, P., Dubey, N.K., Banerji, R. and Chansouria, J.P. 2004. Evaluation of some essential oils as botanical fungitoxicants in management of postharvest rotting of citrus fruits. World Journal of Microbiology and Biotechnology. 20(3):317-321.
Tripathi, P. and Shukla A.K. 2007. Emerging nonconventional technologies for control of post harvest diseases of perishables. Fresh Produce. 1(2):111-120.

Tzortzakis, N.G. 2009. Essential oil: innovative tool to improve the preservation of fresh produce-A review. Fresh Prod. 3:87-97.

Tzortzakis, N.G. and Economakis, C. D. 2007. Antifungal activity of lemongrass (Cympopogon citratus L.) essential oil against key postharvest pathogens. Innovative Food Science \& Emerging Technologies, 8(2), 253-258.

Yang, C., Hamel, C., Vujanovic, V. and Gan, Y. 2011. Fungicide: modes of action and possible impact on nontarget microorganisms. International Scholarly Research Network. : 1-8.

Zeng, R., Zhang, A., Chen, J. and Fu, Y. 2012. Postharvest quality and physiological responses of clove bud extract dip on 'Newhall'navel orange. Scientia Horticulturae, 138:253-258.

Zokaei, K.M., Asna, A.M., Ershadi, A. and Ahmadi, A. 2006. Effect of exogenous putrescine on postharvest life of strawberry (Fragaria ananassa) fruit, cultivar Selva. Agricultural Research, 6(1): 15-25.

(Received on 16.05.2021, Revised on 17.05.2021, Accepted on 28.06.2021) 